\title{
A rare disorder in an infant with Goldenhar syndrome and nephrolithiasis: Alkaptonuria
}

\section{Bir infantta nadir bir hastallk nefrolitiazis ve goldenhar sendromu: Alkaptonüri}

Demet Alaygut', Suar Çakı Kılıç², Meryem Ölmez ${ }^{3}$, Asım Gültekin³, Füsun Dilara İçăgasıoğlu ${ }^{3}$

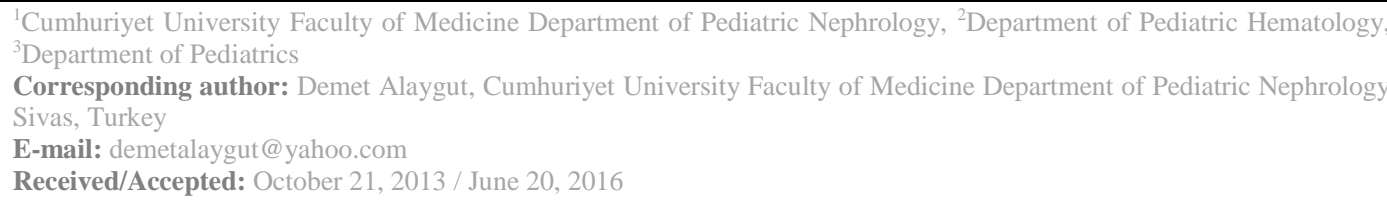

\section{SUMMARY}

Alkaptonuria is a rare disorder of metabolism characterized by deficiency of homogentisic acid oxidase. Characteristic features include darkening of urine, ochronosis, and arthropathy. Darkening of urine is the only sign of the disorder in the pediatric age group. Goldenhar syndrome, also known as oculoauriculovertebral dysplasia, is an uncommon condition, characterized by a incomplete development of the ear, nose, soft palate, lip, and mandible. Renal and genitourinary malformations have also been reported with the complex. A 14-month-old boy with Goldenhar syndrome presented to our clinic with the complaint of nephrolithiasis, and bluish black staining of clothes. There are reports on nephrolithiasis in alkaptonuria (AKU) in middle and late adulthood patients. However, the occurrence of this complication in affected children has not been analysed so far. This report is discussed for the early diagnosis, the development of complication of nephrolithiasis and co-existence with Goldenhar syndrome.

Keywords: Alkaptonuria, goldenhar syndrome, infant, nephrolithiasis

\section{ÖZET}

Alkaptonüri, homogentisik asid oksidaz eksikliği ile karakterize ve nadir görülen bir metabolik hastalıktır. Karakteristik özellikleri, idrar renginde koyulaşma, okranozis ve artropatidir. Pediatrik yaş grubunda idrar renginin koyulaşması tek bulgudur ve hastalığın çok erken dönemlerinde aile tarafından belirtilebilir. Goldenhar sendromu, okuloaurikulovertebral displazi olarak da bilinir ve nadir görülen bir tablodur. Kulak, burun, yumuşak damak, dudak ve mandibula gibi organların vücudun tek tarafinda yeterince gelişememesi sözkonusudur. Renal ve genitoüriner malformasyonlar bu kompleks içinde bildirilmiştir. Goldenhar sendromu tanılı ondört aylık erkek hasta kliniğimize nefrolitiazis ve idrarının değdiği kısımlardaki çamaşırının siyaha dönmesi yakınması ile başvurdu. Özellikle orta ve geç erişkin dönemde alkaptonüri ile birlikte ürolitiazis olguları bildirilmiştir. Bununla birlikte bu komplikasyonun çocuklarda görülmesi konusunda yeterince veri yoktur. Bu vaka erken çocukluk döneminde alkaptonüri tanısı konması, nefrolitiazis komplikasyonunun gelişmiş olması ve Goldenhar sendromu ile birlikte görülmesi nedeni ile sunulmuştur.

Anahtar sözcükler: Goldenhar sendromu, alkaptonüri, nefrolitiazis, infant 


\section{INTRODUCTION}

Alkaptonuria is a disease that is related with the degradation of the tyrosine and develops as a result of the deficiency of homogentisat 1-2 dioxygenase, which is an enzyme of the liver. The reason of deficiency is the mutation that occurs on the gene of homogentisic acid oxidase (HAO) ${ }^{1}$. This enzyme enables transformation of the homogentisic acid (HA) into maleilacetic acid. As a result of the enzyme deficiency, HA accumulates in the body and starts to be excreted abundantly through urine. When the $\mathrm{HA}$ in the tissue and urine encounters with oxygen, it transforms into benzoquinone. Benzoquinones, on the other hand, form melanin-like polymers. Melanin-like polymers are embedded especially in the ligament and cause a brown-black pigmentation on the tissue known as ochronosis. The accumulation of HA and its products causes not only a nigrescence on the tissue color, but also a deterioration on bones, joints, spine and cardiac valves ${ }^{2}$. Darkening in the urine, progressive mottling on the sclera, and ochronotic joint disease are among the characteristic and most frequent symptoms. Goldenhar syndrome or oculo-auriculovertebral dysplasia develops as a result of the developmental anomaly of the first and second branchial arches, is characterized with hemifacial microsomia, eye, ear and vertebral anomalies, and accompanied by cardiac, urogenital, skeletal and central nervous system anomalies ${ }^{3}$. However, it has never been reported to be accompanied by alkaptonuria before. This study discusses about the diagnosis of alkaptonuria as a rare reason of nephrolithiasis in a fourteen-month-old male patient, who had been followed with the diagnosis of Goldenhar syndrome since the neonatal period, and presents this accidental association.

\section{CASE REPORT}

Fourteen-month-old male patient applied to our hospital as a result of the determination of an approximately $9 \mathrm{~mm}$-diameter calculus embedded in the renal pelvis of the right kidney in the renal ultrasonography (USG), performed in the health center where he applied due to discomfort. Mother of the patient, who had no symptom other than discomfort, also informed about a color change of black-brown on the underwear area where his urine contacted. Upon the physical examination, a weight and length of 25-50 percentile, dysmorphic facial appearance, right facial paralysis, low-set small dysmorphic ears, small chin, nasal root flattening and epicantus were determined (Figure 1). The case, which had normal vital symptoms including the blood pressure, had no growth and development retardation. There was no feature in other systemic examination (including sclera, skin, earlap, joints). It was informed from his history that he had urinary tract infection (UTI) for the first time when he was 4 months old and the infection repeated in every two or three months; in addition to the current dysmorphic findings, he had a left renal agenesis and has been followed with the diagnosis of Goldenhar syndrome since the neonatal period. It was also learned from his family history that he was the second child of the family in which mother and father were first degree relatives and he had a sister who had died of the diagnosis of Pierre Robin syndrome. In the laboratory examinations, there was density in the full urine analysis, ph was in normal range, there was proteinuria in the urine, glycosuria was negative and there was no specialty in the microscopic inspection. There was no production in the urinary culture. There was no specialty in simple urinary analysis that had been previously conducted for several times, either. As well as the complete blood count, liver and kidney function tests, uric acid, calcium, phosphorus and other serum electrolytes, 
alkaline phosphatase were in normal ranges. In other examinations performed for stone etiology, it was observed that the blood gas, parathyroid hormone, and $25 \mathrm{OH}$ $D$ vitamin levels were normal. In the urinary biochemistry, on the other hand, it was determined that the ratios of calcium/creatinin; uric acid/creatinin; oxalate/creatinin; citrate/creatinin were normal for his age. $\mathrm{NaOH}$ test was positive in the urinary amino acid chromatography and homogentisic acid was detected in the urine. His urine being kept transformed into black (Figure 2). A first degree reflux was detected on the right kidney as a result of the voiding cystourethrography, which was performed due to the repeating UTI. Prophylactical antibiotic treatment was started. While no activity was observed on the left kidney lobe in the renal DMSA scintigraphy, there was no cortical scar on the right kidney, either. The patient was accepted to have alkaptonuria. As a result of the echocardiography that was performed in terms of other organ involvements, no specialty was determined on the skeletal graphics and eye examination. The patient was given vitamin $\mathrm{C}$ (on dose of 500 $\mathrm{mg} /$ day) for 1 month. He was closely followed with ultrasonography. The stone shrank at first and then could be followed no more with the USG later. The patient has been still followed as outpatient.

\section{DISCUSSION}

Alkaptonuria is a very rare disease (1 in 250.000-1.000.000) with autosomal recessive inheritance. Regarding the disease, the gene HGO is located in areas 21-23 of the long arm of the 3rd chromosome ${ }^{4}$.

Serious symptoms of alkaptonuria appear during adulthood. The first symptom during childhood involves the darkness in the urine and black spots on the diaper. While the urine is normal yellow at first, it transforms

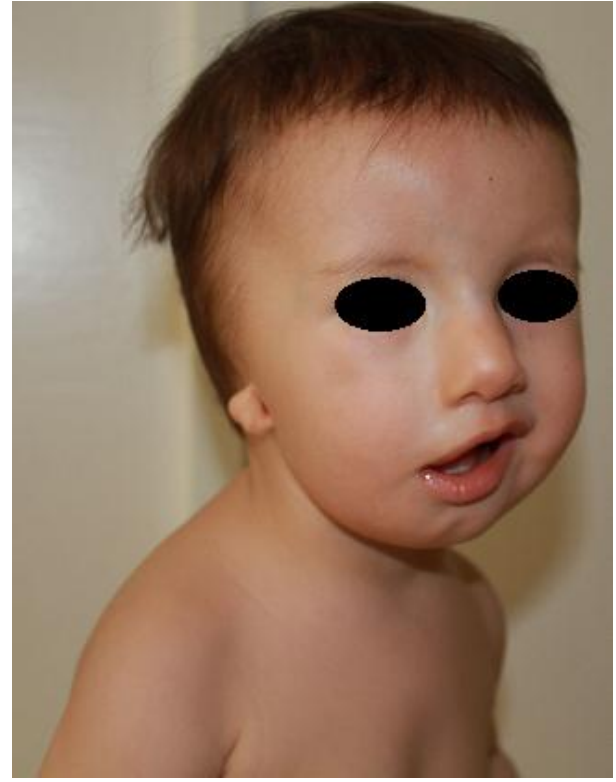

Figure 1. Physical appearance of patient.

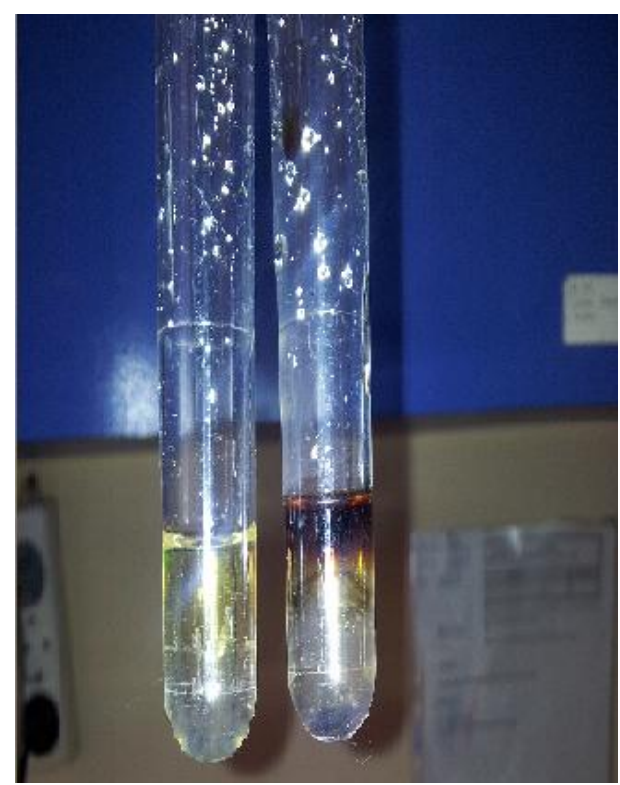

Figure 2. Urine color with $\mathrm{NaOH}$.

into black within a few hours 5 . Alkaptonuria symptoms start to become apparent during the third and fourth decades. The most frequent symptoms include pigmentation on the earlap, sclera and nose wings, and musculoskeletal anomalies (intraarticular narrowing, degeneration, loss of lumbar lordosis caused by disc calcification, thoracic kyphosis, ancylosis, transformation of the urine color to black, calcification and stenosis on cardiac valves) ${ }^{6}$. In a study that was conducted by Phornphutkul et al., they 
examined 58 AKU cases and determined that the age of diagnosis is before age 1 in $21 \%$ of cases and averagely age 29 in others. In these cases, there was urinary condensation in 55\% and chronic joint pain in $45 \%{ }^{2}$. The possibility of joint involvement increases after the age 30 and it develops more rapidly in men. The pigment change on the sclera and cartilage of the ear becomes apparent only after the age 30 , as well. However, similar symptoms were also defined in the pediatric age group. Peker et al. ${ }^{7}$ reported a 4-year-old pediatric patient, who had ochronotic pigment changes on the eye. Our patient had no symptoms of cardiovascular and musculoskeletal system involvement, or pigment change on the sclera and skin.

The development of renal and prostatic calculus is another symptom observed in alkaptonuria ${ }^{8}$. The urine becomes black as a result of the abundant excretion of the homogentisic acid through urine as well as oxidation and polymerization of the homogentisic acid. Homogentisic acid in the urine creates a great susceptibility for the formation of stone ${ }^{6}$. However, nephrolithiasis is not a symptom that is frequently encountered during childhood. In their study, Phornphutkul et al. 2 determined kidney stones in 16 of 58 patients, who had an average age of 64 .

Our patient applied with complaint of nephrolithiasis and as a result of the metabolic screenings, no metabolic reason was determined, except for the positiveness of the $\mathrm{NaOH}$ test. Thus, the stone was considered to be associated with alkaptonuria. However, since our patient had urinary system anomalies and recurrent urinary tract infections, the secondary stone formation should be considered regarding infections, as well.

Renal failure could rarely be encountered in patients with alkaptonuria. Renal biopsy might detect tubular atrophy, interstitial fibrosis, inflammation, and diffuse chronic tubulointerstitial that is characterized with a melanin-like pigment accumulation on tubular cells ${ }^{9}$. Renal glomerular and tubular function tests of our patient were normal. However, he is required to be followed closely, since he has a solitary kidney and the solitary kidney is accompanied by vesicoureteral reflux and early-onset alkaptonuria and nephrolithiasis.

There are several cases identified in literature related with alkaptonuria. These are generally accompanied by the musculoskeletal system and cardiac involvements of alkaptonuria. However, association of the Goldenhar syndrome and alkaptonuria has never been encountered.

In Goldenhar syndrome, the most frequent anomalies are observed on the eye, ear, vertebra and craniofacial area in the oculoauriculo-vertebral spectrum. Ear anomaly is a must for the diagnosis. Ear anomalies could be seen as preauricular skin tag, microtia and anotia. Being generally sporadic, it also is a genetic picture that is encountered in family cases with autosomal dominant and recessive inheritance ${ }^{3}$. Developing in various ways, craniofacial anomalies are frequently accompanied by facial asymmetry or hemifacial microsomia. Mandibular hypoplasia, facial muscle hypoplasia, facial paralysis, cleft palate and lip, and highly arched palate are among other craniofacial anomalies. Our case had preauricular skin tag, mikrotia, facial asymmetry and mandibular hypoplasia. Goldenhar syndrome might be accompanied by other system anomalies (cardiac, genitourinary, central nervous system, eye and vertebra) at a rate of $50 \%{ }^{3}$. Vesicoureteral reflux, hydronephrosis, ureteropelvic narrowness might be present as associated with genitourinary system anomalies ${ }^{3}$. Our case had genitourinary system anomalies including left renal agenesis and first degree vesicourethral reflux on right.

Alkaptonuria does not have a definite treatment. Protein restriction is not generally sufficient in order to decrease 
tyrosine and phenylalanine levels. Ascorbic acid prevents the oxidation and polymerization of the homogentisic acid as in vitro. There is not a consensus on the benefit of the ascorbic acid that is used in order to avail of its antioxidant effect yet ${ }^{10}$. The treatment of ascorbic acid was applied to our patient for one month. However, it is not possible to associate the fact that his stone shrank and then could not be determined through ultrasonography with the ascorbic acid that was given. The only treatment, whose efficiency has been proven, is the nitisinone treatment today. This medicine creates an effect by obstructing the enzyme of 4hydroxyphenylpryruvate dioxygenase, which enables the formation of homogentisat in the degradation of tyrosine $^{10}$. Nitisinone has two important side effects. The first one is that it increases the level of serum tyrosine and causes dryness, stinging pain on the eye, sensitivity to light, corneal corruption and formation of crystal. The second one is that it creates Type 3 tyrosinemia in an artificial way, and this disease has the most frequent effects on the brain. It is recommended to restrict the protein of the patient in order to avoid both important side effects. However, there have been still uncertainties about the most convenient age to start the treatment, duration of the treatment and its other possible side effects ${ }^{10}$.

As a consequence, since it clinically involves a large spectrum, Goldenhar syndrome is important and it requires systemic examinations. The interesting point is that this patient, who had been followed with the Goldenhar syndrome, applied with nephrolithiasis and alkaptonuria was determined as the underlying etiologic reason. Even though application for the alkaptonuria, which might cause serious effects in advanced ages, generally is made with the complaint of darkening in the urine color in age group of childhood, the renal stone formation, which is one of the symptoms, should also be taken into consideration and patients should closely be followed in terms of possible renal failure.

\section{REFERENCES}

1. Fernandez-Canon JM, Granadino B, Beltran-Valero de Bernabe D. The molecular basis of alkaptonuria. Nat Genet 1996; 14 : 19-24.

2. Phornphutkul C, Introne WJ, Perry MP. Natural history of alkaptonuria. N Engl J Med 2002; 347: 2111-21.

3. Hartsfield JK. Review of the etiologic heterogenity of the oculoauriculo-vertebral spectrum (Hemifacial Microsomia) Orthod Craniofac Res 2007; 10: 121-8.

4. Robert Raphael Aquaron. Alkaptonuria in France: Past experience and lessons for the future. J Inherit Metab Dis 2011; 34: 1115-26.

5. Verma SB. Early detection of alkaptonuria. Indian J Dermatol Venereol Leprol 2005; 71: 189-91.

6. Sridhar FK, Mukha RP, Kumar S. Lower urinary tract symptoms and prostatic calculi: A rare presentation of alkaptonuria Indian J Urol 2012; 28: 219-21.

7. Peker E, Yonden Z, Sogut S. From darkening urine to early diagnosis of alkaptonuria. Indian J Dermatol Venereol Lepra 2008; 74: 700.

8. Keller JM, Macaulay W, Nercessian OA. New developments in ochronosis: Review of the literature. Rheumatol Int 2005; 25 : 81-5.

9. Venkataseshan VS, Chandra B, Graziano V. Alkaptonuria and renal failure: A case report and review of the literature. Mod Pathol 1992; 5: 464-71.

10. Suwannarat P, O'Brien K, Perry MB. Use of nitisinone in patients with alkaptonuria. Metabolism 2005; 54: 719-28. 